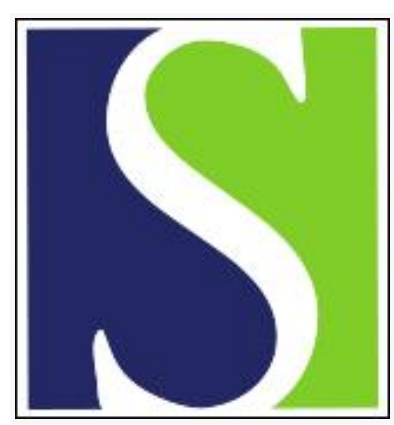

Scand J Work Environ Health 1991;17(5):347-355

https://doi.org/10.5271/sjweh.1693

Issue date: Oct 1991

Changes in muscle morphology in chronic trapezius myalgia.

by Lindman R, Hagberg M, Angqvist KA, Soderlund K, Hultman E, Thornell LE

Affiliation: Department of Anatomy, University of Umea, Sweden.

This article in PubMed: www.ncbi.nlm.nih.gov/pubmed/1947920 


\title{
Changes in muscle morphology in chronic trapezius myalgia
}

\author{
by Rolf Lindman, DDS, ${ }^{1}$ Mats Hagberg, MD, ${ }^{2}$ Karl-Axel Ängqvist, MD, ${ }^{3}$ \\ Karin Söderlund, ${ }^{4}$ Eric Hultman, MD, ${ }^{4}$ Lars-Eric Thornell, MD ${ }^{1}$
}

\begin{abstract}
LINDMAN R, HAGBERG M, ÄNGQVIST K-A, SÖDERLUND K, HULTMAN E, THORNELL L-E. Changes in muscle morphology in chronic trapezius myalgia. Scand J Work Environ Health 1991;17: 347-55. Muscle biopsies of the descending portion of the trapezius muscle from female patients with chronic trapezius myalgia and from healthy women were analyzed with enzyme histochemical and immunohistochemical methods. Frequency, area, and capillarization of the muscle fiber types were determined. A biochemical analysis determined the lactate concentration of mixed muscle samples and the adenosine triphosphate (ATP) and phosphocreatine levels in single muscle fibers. The patients had larger type I fibers and a lower capillary:fiber area ratio for type I and type IIA fibers. The patients also exhibited lower levels of ATP and phosphocreatine in both type I and type II fibers. It is suggested that there might have been an imbalance between the capillary supply and the cross-sectional fiber area of type I and type IIA fibers in the patients. This imbalance might be of significance in the development of muscular fatigue and pain.
\end{abstract}

Key terms: adenosine triphosphate, capillary supply, chronic pain, fiber types, trapezius muscle.

The descending portion of the trapezius muscle is normally subjected to frequent loading to support and stabilize the shoulders during movements of the upper extremities (1). Work conditions with static and repetitive tasks cause an additional load on the shoulder muscles, and it appears that low-intensity loads over a long period of time and static loads cause a particular problem (2-4). The major complaint reported among patients with work-related disorders is chronic tenderness and pain in the muscles of the neck and shoulders (5-10). A myogenic cause of chronic workrelated neck-shoulder pain is suggested by the increased rate of fatigue indicated by electromyography (8), the low elevation strength (11), and the inability to generate high amplitude motor units (12). Ischemia is thought to be a significant factor in occupational muscle disorders $(11-14)$. Recent findings of morphological and biochemical changes in muscle biopsies from patients with work-related trapezius myalgia have been suggested to be related to local temporary hypoxia and reduced muscle oxygenation (15), possibly due to reduced blood flow (16). Furthermore, an energy crisis within the muscle fibers has been suggested as a possible cause of chronic muscular pain $(15,17)$.

The use of enzyme histochemistry and the concept of muscle fiber types has been of great importance in the understanding of muscle physiology and patho-

1 Department of Anatomy, University of Umeå, Umeå, Sweden.

2 Division of Work and Environmental Physiology, National Institute of Occupational Health, Solna, Sweden.

3 Department of Surgery, University of Umeå, Umeå, Sweden.

4 Department of Clinical Chemistry II, Huddinge University Hospital, Huddinge, Sweden.

Reprint requests To: Professor L-E Thornell, Department of Anatomy, University of Umeå, S-901 87 Umeå, Sweden. physiology. Muscle fibers can be classified into different fiber types according to the reaction of myofibrillar adenosine triphosphatase (mATPase) at different levels of alkaline and acidic preincubations (18, 19). The histochemical fiber type composition can be correlated with the physiological properties $(20-24)$ and can thereby give an indication of the contractile and metabolic properties of the muscle. Thus type I fibers are slow contracting and fatigue resistant, type IIA fibers are fast contracting and fatigue resistant, and type IIB fibers are fast contracting but fatigue sensitive.

Although previous results have shown morphological changes thought to be related to muscle oxygenation $(15,16)$ and also changes in the fiber type population in patients with chronic trapezius myalgia (15), there are no studies on fiber type composition which include the type II fiber subtypes and muscle fiber capillarization in such patients. Therefore, we have carried out such a study on female patients with longstanding static and repetitive loading of the neck and shoulder muscles and a long history of pain. We have then compared these results with that of healthy female subjects.

\section{Subjects and methods}

Muscle biopsies were obtained from patients who had been referred to the Department of Occupational Medicine due to suspected chronic work-related myalgia in the muscles of the neck and shoulders. In the present study, male subjects were excluded, and also one female subject who was not subjected to static or repetitive work was omitted. In addition, two female subjects were later excluded due to artifacts in the biopsies. Thus 10 female patients with a mean age 
of 45.5 (range 27-58) years were included. According to detailed work history recordings, these patients had been exposed to static and highly repetitive work tasks for an average of 15 (range $4-22$ ) years. Their job titles were cashier $(\mathrm{N}=2)$, charwoman $(\mathrm{N}=1)$, assembly worker $(\mathrm{N}=5)$, microscopist $(\mathrm{N}=1)$, and spray lacquerer $(\mathrm{N}=1)$. No exposure measurements were performed. Their mean duration of symptoms was 7 (range 4-13) years. At the time of the biopsy, all the patients were on sick leave and had been so for an average of 2.4 (range 14 days -7 years) years. Two patients were smokers and three were ex-smokers. For eight patients, the diagnosis did not conform to fibrositis or primary fibromyalgia since the pain was localized in the shoulder and neck region only. Two patients had signs of more generalized pain, but both had been exposed to static and repetitive load and, therefore, occupational trauma could not be excluded. An extensive clinical, radiographic, and laboratory examination of the patients showed no signs of inflammatory rheumatic disease, neuromuscular disease, or cervical root engagement. Two patients had degenerative changes of the osteophytic type, however, not on the biopsy side. None had a radiograph indicative of severe spondyloarthrosis or impingement of cervical nodes or the spinal cord. During time on sick leave, all the patients went through a program of physiotherapy, however, at very low intensities and loads and for a short duration because of the pain. Attempts at rehabilitation were unsuccessful.

Five healthy females with a mean age of 35 (range 32-39) years with no history of chronic shoulder or neck muscle pain served as the referents. Three of the referents were medical doctors, one was a physiotherapist, and one was a nurse. None of the referents performed static or repetitive work tasks, and they were all only moderately physically active.

\section{Biopsy, enzyme histochemical and immunohisto- chemical procedures}

Biopsies were taken with an open surgical technique. For the patients, a biopsy was taken from a tender point in the upper region of the descending portion of the trapezius muscle. In the reference group, the biopsy was taken from the same area. A portion of the muscle sample was separated and immediately frozen in liquid nitrogen for the biochemical analyses. Another part was oriented in $\mathrm{OCT}^{\circledR}$ embedding medium (Miles Laboratories, Naperville, IL, United States) on cardboard and rapidly frozen in propane chilled to $-160^{\circ} \mathrm{C}$ and stored at $-80^{\circ} \mathrm{C}$ until use. Serial transverse sections, $10 \mathrm{~mm}$ thick, were cut in a cryostat ultramicrotome at $-20^{\circ} \mathrm{C}$ and mounted on glass slides. The sections were then stained for the reaction of mATPase (EC 3.6.1.3) at pH 9.4 $(18,25)$ and at different levels of preincubation, $\mathrm{pH} 4.6$ and 4.3 (19). In addition we used preincubation at $\mathrm{pH} 4.7$. Nicotinamide dinucleotide dehydrogenase tetrazolium oxido-reductase (NADH-TR) (EC 1.6.99.3), glycerol- 3-phosphate oxidoreductase (EC 1.1.99.6), and phosphorylase were used to show oxidative and glycolytic activity. Modified Gomori trichrome staining (26) was used to identify nuclei and cell borders. Oil red $O$ was used to identify the lipids.

Rabbit polyclonal antibodies against laminin isolated by affinity chromatography from sarcomas and produced by E-Y lab, INE, San Mateo, California, United States, were used to stain the basement membranes. The peroxidase-antiperoxidase technique (27) was used to visualize the presence of the laminin, displaying the basement membrane of the capillaries in sections serial to those used for the fiber typing.

\section{Sampling of fibers, fiber area measurements and capillary count}

The muscle fibers were typed, according to their mATPase lability at different levels of preincubation acidity, into type I, IIA, IIB, IIC (19), IIAB (28), and IM (29) fibers. The analyses were based on three randomly selected areas from each sample. Photographs were taken with a Leitz (Dialux 20) light photomicroscope, magnified to $620 \times$ before the measuring on a Hipad digitizing table (Huston instruments) connected to an ABS 800 personal computer programmed for morphometric analyses. Capillaries in contact with each fiber type $(\mathrm{CF})$ and the $\mathrm{CF}$ relative to the cross-sectional fiber area of the fiber types $(\mathrm{CA})$ was determined.

\section{Biochemistry}

One part of the samples was dissected free from blood and connective tissue and extracted with $0.5 \mathrm{M}$ perchloric acid containing $1.0 \mathrm{mM}$ ethylenediaminetetraacetic acid (EDTA). These pieces were neutralized with $2.2 \mathrm{M}$ potassium hydrogen carbonate $\left(\mathrm{KHCO}_{3}\right)$. The neutralized extracts were analyzed enzyme histochemically for lactate as described by Harris et al (30).

One part of the freeze-dried muscle sample was used for fiber separation and the analysis of adenosine triphosphate (ATP) and phosphocreatine in single muscle fibers. To exclude the admission of extramuscular tissue in the analyzed material, we separated the fibers and analyzed individual characterized fibers. Two small pieces were cut from each fiber and used for classifying the fibers into type I and type II according to their staining characteristics for mATPase. The remaining part of the fibers was weighed on a quartzfiber fishpole balance as described by Lowry \& Passonneau (31). Each fiber was then extracted in $200 \mathrm{ml}$ of $2.5 \%$ trichloroacetic acid for approximately 2-3 min and neutralized with $20 \mathrm{ml}$ of $2.2 \mathrm{M}$ $\mathrm{KHCO}_{3}$ and stored at $-70^{\circ} \mathrm{C}$ until analyzed. By using a bioluminescence technique, we were able to determine the ATP and phosphocreatine content in single fibers (weighing $1-4 \mathrm{mg}$ ) using a creatine kinase (EC 2.7.3.2.) total kit 1243-100 LKB Wallac (32) modified for this purpose (33). The analyses were performed with a Pharmacia LKB-Wallac 1251 luminometer (Turku, Finland). 


\section{Statistical methods}

Mean values and standard deviations were calculated. Since the sample size was small, differences in the frequency and area of the muscle fibers, as well as the fiber capillarization between the groups, were tested for significance with the Mann-Whitney analysis of variance. Significance was set at the 0.05 level.

The mean value for ATP and phosphocreatine in single fibers from five patients was compared with the mean value from five healthy subjects (reference value). The test used was "simple significance tests based on normal distribution comparison of means of two large sample sizes"' (34).

\section{Results}

Muscle fiber types, frequency and size

Generally, type I, type IIA, type IIAB, and type IIB fibers were identified (figure 1). Type I and type IIA fibers constituted the majority of the fiber population. Type I fibers predominated in both the patients and the referents and were the most marked in the patients. Type IIB fibers were absent in one patient, and both type IIAB and type IIB fibers were absent in two patients and one referent. Type IIC and IM fibers rarely occurred. However, in one patient type IIC fibers constituted $2 \%$ of the total fiber population.
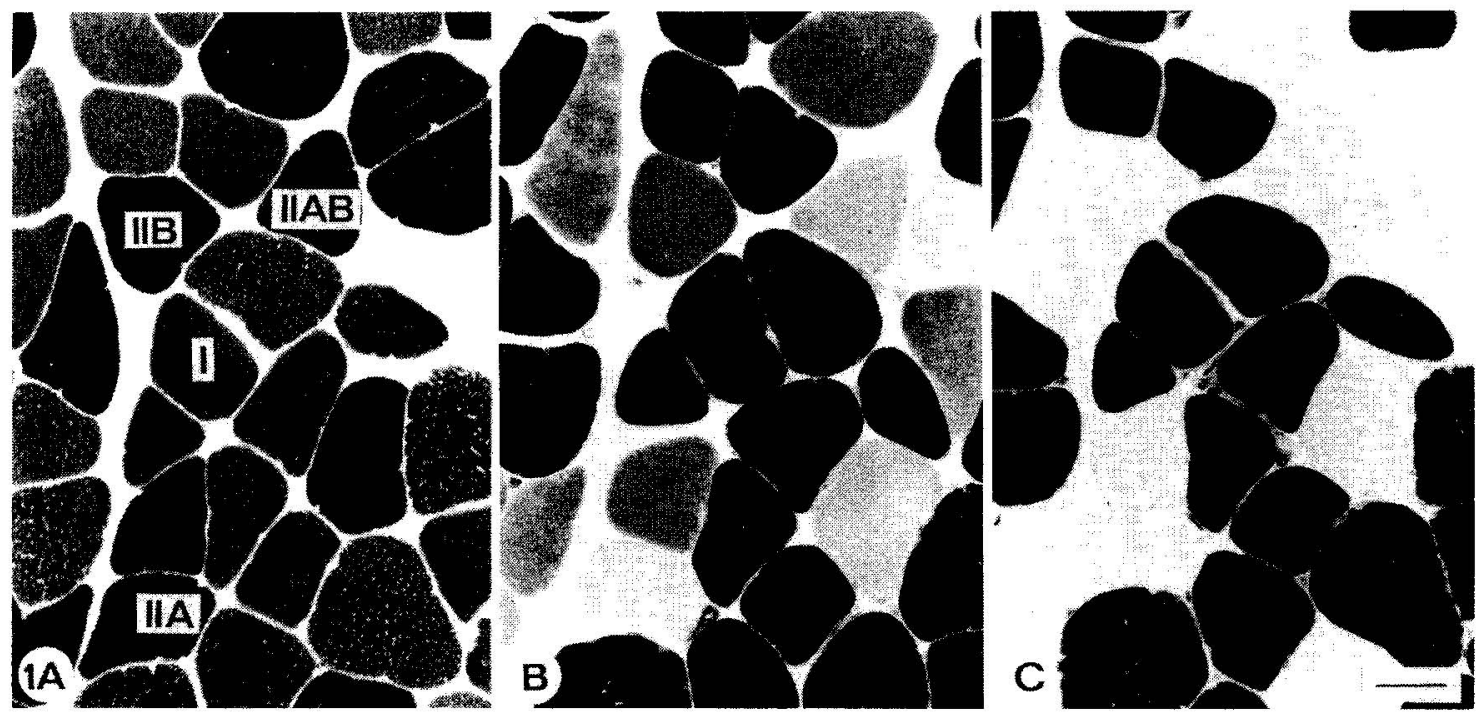

Figure 1. Serial cross-sections from the trapezius muscle showing the different muscle fiber types when stained for myofibrillar adenosine triphosphatase at $\mathrm{pH} 9.4(\mathrm{~A}), 4.6(\mathrm{~B})$, and $4.3(\mathrm{C})$. Type I, type IIA, IIAB, and type IIB fibers are marked. $(\mathrm{bar}=40 \mu \mathrm{m})$

Table 1. Mean frequency, cross-sectional area, capillaries per fiber type ratio (CF ratio), and CF ratio relative to the fiber type area $(\mathrm{CA})$ of the patients and referents.

\begin{tabular}{|c|c|c|c|c|c|c|c|c|}
\hline \multirow{2}{*}{ Fiber type } & \multicolumn{2}{|c|}{$\begin{array}{l}\text { Fiber type frequency } \\
\qquad(\%)\end{array}$} & \multicolumn{2}{|c|}{$\begin{array}{l}\text { Fiber type area } \\
\qquad\left(\mu \mathrm{m}^{2}\right)\end{array}$} & \multicolumn{2}{|c|}{ CF ratio } & \multicolumn{2}{|c|}{$\mathrm{CA}$} \\
\hline & Mean & SD & Mean & SD & Mean & SD & Mean & SD \\
\hline \multicolumn{9}{|l|}{1} \\
\hline $\begin{array}{l}\text { Patients } \\
\text { Referents }\end{array}$ & $\begin{array}{l}64.3 \\
55.8\end{array}$ & $\begin{array}{l}12.6 \\
26.0\end{array}$ & $\begin{array}{l}4720^{* *} \\
2831\end{array}$ & $\begin{array}{r}1262 \\
721\end{array}$ & $\begin{array}{l}3.54 \\
3.15\end{array}$ & $\begin{array}{l}0.69 \\
0.94\end{array}$ & $\begin{array}{l}0.80^{*} \\
1.12\end{array}$ & $\begin{array}{l}0.24 \\
0.26\end{array}$ \\
\hline \multicolumn{9}{|l|}{$\| A$} \\
\hline $\begin{array}{l}\text { Patients } \\
\text { Referents }\end{array}$ & $\begin{array}{l}25.9 \\
29.2\end{array}$ & $\begin{array}{l}10.6 \\
21.0\end{array}$ & $\begin{array}{l}4159 \\
2752\end{array}$ & $\begin{array}{r}1728 \\
747\end{array}$ & $\begin{array}{l}2.58 \\
2.69\end{array}$ & $\begin{array}{l}0.85 \\
0.33\end{array}$ & $\begin{array}{l}0.64^{*} \\
1.04\end{array}$ & $\begin{array}{l}0.30 \\
0.33\end{array}$ \\
\hline \multicolumn{9}{|l|}{$\mathrm{IIAB}$} \\
\hline $\begin{array}{l}\text { Patients } \\
\text { Referents }\end{array}$ & $\begin{array}{l}5.1 \\
4.2\end{array}$ & $\begin{array}{l}4.2 \\
2.4\end{array}$ & $\begin{array}{l}4003 \\
2674\end{array}$ & $\begin{array}{r}1767 \\
875\end{array}$ & $\begin{array}{l}2.36^{* *} \\
1.81\end{array}$ & $\begin{array}{l}0.39 \\
0.24\end{array}$ & $\begin{array}{l}0.66 \\
0.75\end{array}$ & $\begin{array}{l}0.18 \\
0.31\end{array}$ \\
\hline \multicolumn{9}{|l|}{ IIB } \\
\hline $\begin{array}{l}\text { Patients } \\
\text { Referents }\end{array}$ & $\begin{array}{r}4.7 \\
10.8\end{array}$ & $\begin{array}{r}8.4 \\
10.9\end{array}$ & $\begin{array}{l}4144 \\
2408\end{array}$ & $\begin{array}{r}2088 \\
760\end{array}$ & $\begin{array}{l}2.62 \\
1.84\end{array}$ & $\begin{array}{l}0.47 \\
0.52\end{array}$ & $\begin{array}{l}0.60 \\
0.81\end{array}$ & $\begin{array}{l}0.17 \\
0.28\end{array}$ \\
\hline
\end{tabular}

* $P<0.05,{ }^{*} * P<0.01$. 

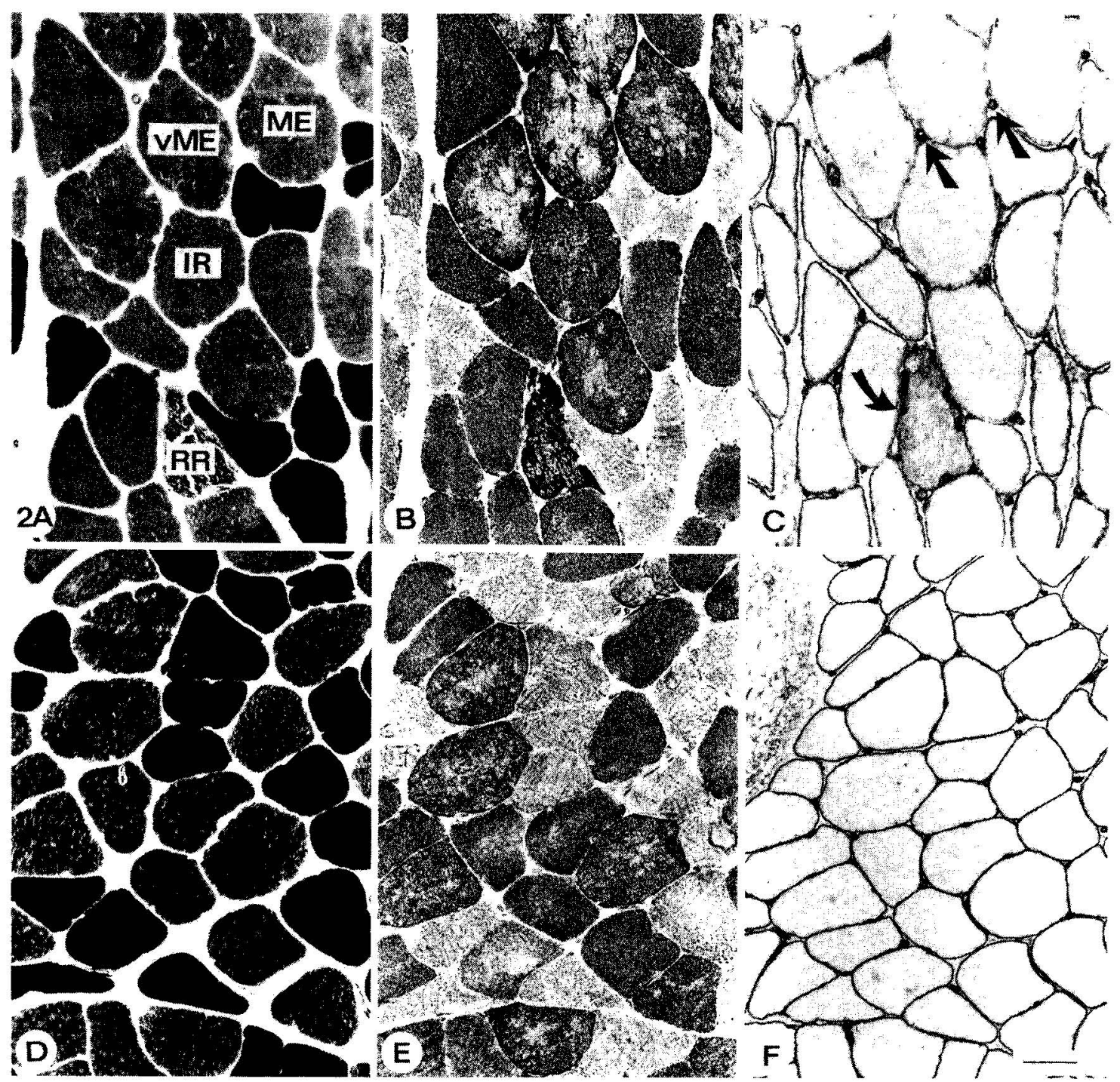

Figure 2. Serial cross-sections from the trapezius muscle of a patient $(A-C)$ and a reference subject $(D-F)$ stained for myofibrillar adenosine triphosphatase at $\mathrm{pH} 9.4(\mathrm{~A}, \mathrm{D})$, nicotinamide dinucleotide dehydrogenase tetrazolium oxido-reductase (B, E), and laminin (C, F). Note the large differences in fiber area, especially that of type I fibers, between the patient and the referent. Fibers with whorling of the intermyofibrillar network (IR) and focal losses of enzyme activity [moth-eaten (ME) and very moth-eaten (VME) fibers], as well as a ragged-red fiber (RR) are shown. The peroxidase-antiperoxidase staining with antilaminin antibodies clearly marks the basement membrane of the capillaries (arrows). Note also the high number of capillaries surrounding the ragged-red fiber $(C)$. (bar $=40 \mu \mathrm{m})$

The relative frequency and the mean cross-sectional fiber area of the fiber types are presented in table 1 . When stained by nicotinamide dinucleotide dehydrogenase tetrazolium oxido-reductase, the type I fiber population showed differences in the staining pattern. In general, the type I fibers showed an even distribution of formazan deposits, and the intermyofibrillar network had a regular honeycomb pattern. Fibers with an irregular intermyofibrillar network and clusters of formazan deposits were also observed. We refer to them as "irregular fibers" ( $I_{I R}$ fibers) (figure 2). Fibers with focal loss of enzyme activity and whorling of the intermyofibrillar network are referred to as moth-eaten fibers ( $\mathrm{I}_{\mathrm{ME}}$ fibers) (figures 2 and 3). Within the $I_{M E}$ fiber population there were fibers with large patches of activity loss. We refer to them as "very" moth-eaten fibers ( $I_{\mathrm{vME}}$ fibers) (figures 2 and 3).

Generally speaking, the moth-eaten fibers were evenly distributed over the cross-section and they were always of type I. Irregular fibers and moth-eaten fibers were observed in six patients and four referents. "Very" moth-eaten fibers were seen in four patients and three referents. The frequency of these fibers with- 

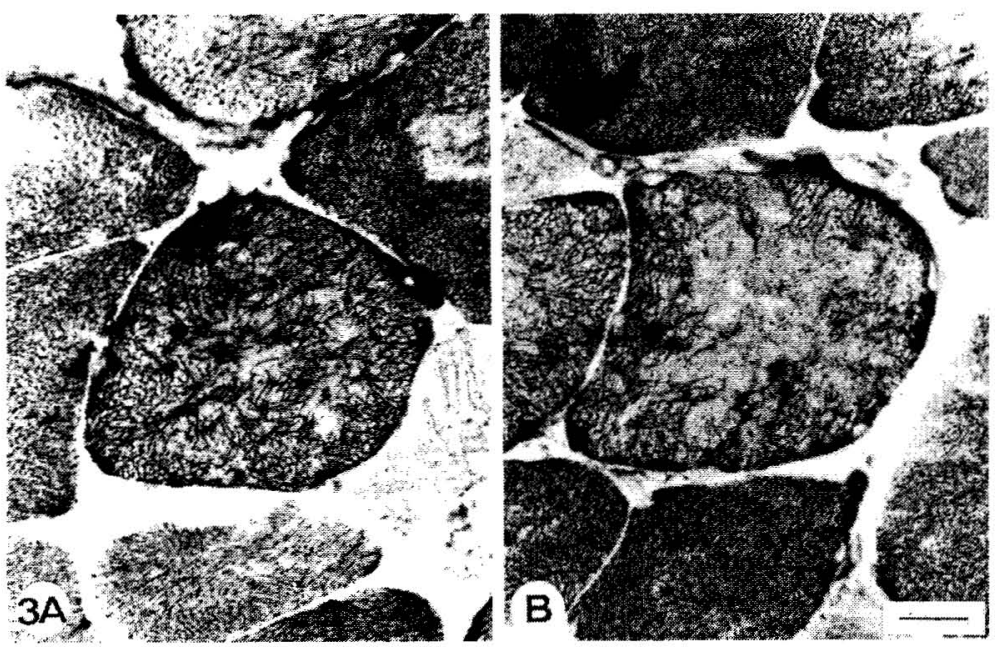

Figure 3. Cross-sections stained for nicotinamide dinucleotide dehydrogenase tetrazolium oxido-reductase showing the structural architecture of two moth-eaten fibers. One with whorling of the intermyofibrillar network $(3 A)$ and one with loss of enzyme activity (3B). (bar $=16 \mu \mathrm{m})$

Table 2. Mean frequency, cross-sectional area, capillaries per fiber type ratio ( $C F$ ratio), and CF relative to fiber type area (CA) for the "irregular" $\left(I_{I R}\right)$, moth-eaten $\left(I_{M E}\right)$, and "very" moth-eaten ( $\left.I_{V M E}\right)$ fibers of the patients and the referents.

\begin{tabular}{|c|c|c|c|c|c|c|c|c|}
\hline \multirow{2}{*}{ Fiber type } & \multicolumn{2}{|c|}{$\begin{array}{c}\text { Fiber type } \\
\text { frequency }(\%)\end{array}$} & \multicolumn{2}{|c|}{$\begin{array}{l}\text { Fiber type area } \\
\qquad\left(\mu \mathrm{m}^{2}\right)\end{array}$} & \multicolumn{2}{|c|}{ CF } & \multicolumn{2}{|c|}{$\mathrm{CA}$} \\
\hline & Mean & SD & Mean & SD & Mean & SD & Mean & SD \\
\hline \multicolumn{9}{|l|}{$I_{I R}$} \\
\hline $\begin{array}{l}\text { Patients } \\
\text { Referents }\end{array}$ & $\begin{array}{l}4.4 \\
3.2\end{array}$ & $\begin{array}{l}5.0 \\
2.8\end{array}$ & $\begin{array}{l}5561 \\
3104\end{array}$ & $\begin{array}{l}1106^{* *} \\
1097\end{array}$ & $\begin{array}{l}3.55 \\
3.40\end{array}$ & $\begin{array}{l}9.81 \\
0.39\end{array}$ & $\begin{array}{l}0.68^{\star \star} \\
1.08\end{array}$ & $\begin{array}{l}0.22 \\
0.18\end{array}$ \\
\hline \multicolumn{9}{|l|}{$\mathrm{I}_{\mathrm{ME}}$} \\
\hline $\begin{array}{l}\text { Patients } \\
\text { Referents }\end{array}$ & $\begin{array}{l}3.3 \\
8.6\end{array}$ & $\begin{array}{l}3.6 \\
7.8\end{array}$ & $\begin{array}{l}5406 \\
3849\end{array}$ & $\begin{array}{r}2081 \\
703\end{array}$ & $\begin{array}{l}4.22 \\
3.71\end{array}$ & $\begin{array}{l}0.85 \\
0.22\end{array}$ & $\begin{array}{l}0.84 \\
0.99\end{array}$ & $\begin{array}{l}0.38 \\
0.20\end{array}$ \\
\hline \multicolumn{9}{|l|}{$\mathrm{I}_{\mathrm{VME}}$} \\
\hline $\begin{array}{l}\text { Patients } \\
\text { Referents }\end{array}$ & $\begin{array}{l}2.7 \\
1.6\end{array}$ & $\begin{array}{l}4.0 \\
1.5\end{array}$ & $\begin{array}{l}7286 \\
4345\end{array}$ & $\begin{array}{r}2362 \\
286\end{array}$ & $\begin{array}{l}4.30 \\
3.86\end{array}$ & $\begin{array}{l}0.8 \\
0.9\end{array}$ & $\begin{array}{l}0.64 \\
0.89\end{array}$ & $\begin{array}{l}0.29 \\
0.24\end{array}$ \\
\hline
\end{tabular}

$\star * P<0.01$.

in the type I fiber population and their mean crosssection fiber area and standard deviation are presented in table 2.

Fibers with a subsarcolemmal accumulation of formazan particles in NADH-TR in the same zones as reddish blue material in the Gomori trichrome staining were referred to as ragged-red fibers (figure 2). The ragged-red fibers showed higher levels of intracellular lipids than the ordinary type I fibers when stained by oil red O (figure 4). Ragged-red fibers were observed in one patient and one referent, one in each biopsy.

The average number of capillaries in contact with each fiber type (CF) was higher for the type I fibers than for the type II fibers in both the patients and the referents. When the CF was expressed relative to the mean cross-sectional fiber area, this value (CA) was also higher for the type I than the type II fibers in both groups. Both the CF and CA varied between individuals in both the patient group and the reference group. The mean values and standard deviations for the CF and $\mathrm{CA}$ ratios are given in tables 1 and 2 .

\section{Significant differences in the fiber type composition and capillary supply}

The type I fibers and the irregular fibers were significantly larger in the patients than in the referents. In the patients the $\mathrm{I}_{\mathrm{vME}}$ fibers were larger than the type IIA fibers. In the referents the $I_{\mathrm{vME}}$ fibers were larger than the type IIB fibers. There was a significantly higher $\mathrm{CF}$ ratio for the type IIAB fibers in the patients than in the referents. Within the patient group, the $\mathrm{CF}$ value was higher for the type $I$ and the $I_{I R}$ fibers than for the type IIAB fibers. However, in the reference group, the CF value was higher for all type I fibers than for the type IIAB and type IIB fibers. The CA ratio was significantly lower for the patients than for the referents regarding type $I, I_{I R}$, and IIA fibers.

\section{Biochemistry}

The ATP and phosphocreatine concentrations determined for fibers isolated from the five freeze-dried muscle samples from the patient group were significantly lower than corresponding concentrations ob- 

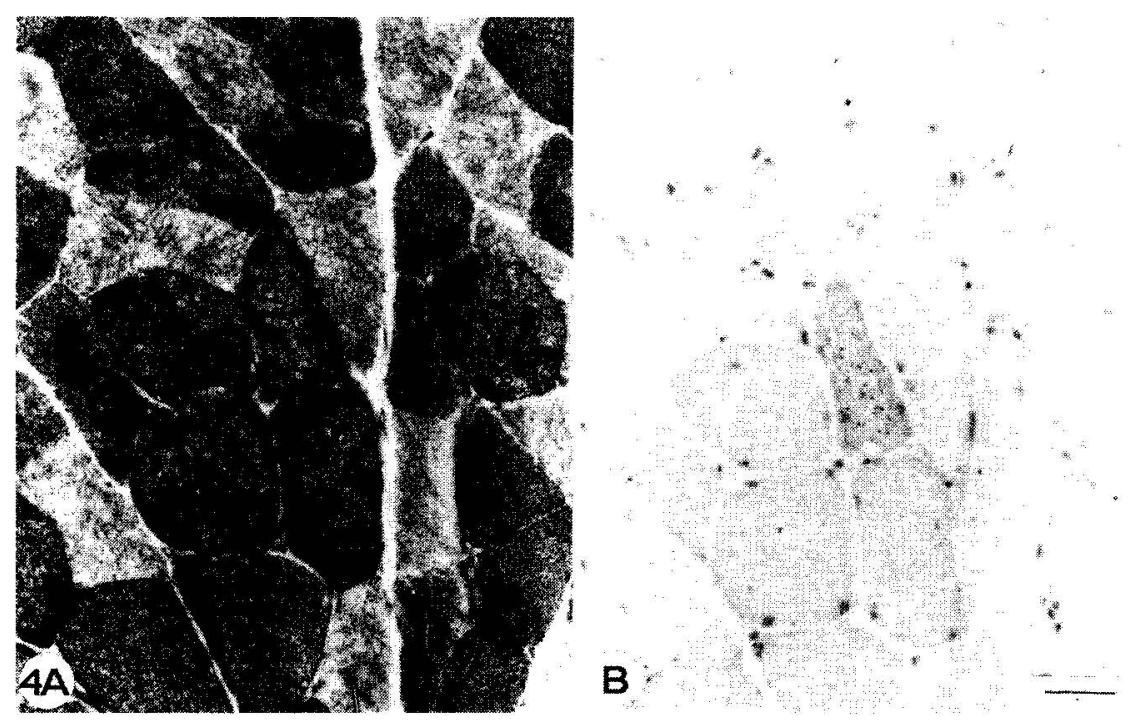

Figure 4. Serial crosssection of a ragged-red fiber (center) stained for nicotinamide dinucleo. tide dehydrogenase tetrazolium oxido-reductase activity (A) and with oil red $O$ (B). Note the accumulation of lipid droplets within the ragged-red fiber. $($ bar $=26 \mu \mathrm{m})$

Table 3. Concentration of adenosine triphosphate (ATP) and phosphocreatine in single fibers and the lactate concentration in whole muscle samples from the trapezius muscle of the patients with chronic trapezius myalgia. Reference values represent the corresponding values of five healthy women.

\begin{tabular}{|c|c|c|c|c|c|c|c|c|c|c|c|c|c|c|c|}
\hline \multirow[b]{4}{*}{$\begin{array}{l}\text { Patient } \\
\text { values }\end{array}$} & \multicolumn{6}{|c|}{ ATP } & \multicolumn{6}{|c|}{ Phosphocreatine (mmol/kg of dry muscle tissue) } & \multirow{2}{*}{\multicolumn{3}{|c|}{ Lactate }} \\
\hline & \multicolumn{3}{|c|}{ Type I } & \multicolumn{3}{|c|}{ Type II } & \multicolumn{3}{|c|}{ Type I } & \multicolumn{3}{|c|}{ Type II } & & & \\
\hline & $\begin{array}{c}\text { Number } \\
\text { of } \\
\text { samples }\end{array}$ & Mean & SD & $\begin{array}{l}\text { Number } \\
\text { of } \\
\text { samples }\end{array}$ & Mean & SD & $\begin{array}{l}\text { Number } \\
\text { of } \\
\text { samples }\end{array}$ & Mean & SD & $\begin{array}{c}\text { Number } \\
\text { of } \\
\text { samples }\end{array}$ & Mean & SD & $\begin{array}{c}\text { Number } \\
\text { of } \\
\text { samples }\end{array}$ & Mean & SD \\
\hline & 49 & 14.8 & $2.47^{* * *}$ & 28 & 18.8 & $1.79^{* * \star}$ & 49 & 58.7 & $9.59^{* *}$ & 28 & 86.5 & $13.8^{* *}$ & 5 & 3.74 & 1.13 \\
\hline $\begin{array}{l}\text { Reference } \\
\text { values }\end{array}$ & 60 & 20.2 & 4.70 & 113 & 25.2 & 3.09 & 50 & 65.9 & 14.8 & 95 & 97.1 & 16.2 & 5 & 5.01 & 1.7 \\
\hline
\end{tabular}

** $P<0.01, * * * P<0.001$

tained from the five healthy female volunteers (table 3). Lactate concentration determined in whole muscle samples had similar values in both groups.

\section{Discussion}

All the fibers, irrespective of type, tended to have a larger mean cross-sectional fiber area in the patients than in the referents, the type $\mathrm{I}$ and type $\mathrm{I}_{\mathrm{IR}}$ fibers being significantly larger. The type I fibers belong to motor units which are the first to be recruited during repetitive movements of relatively low tension (21). The larger area of the fibers in the patient biopsies, obtained from tender points, may reflect an adaptive response to frequent occupational use of this region of the muscle since muscular usage might cause an increase in fiber area $(35,36)$. However, one might then expect the fiber size to be normalized in the patients since they had been on sick leave for a long period of time. One possible explanation is that this assumed increase in fiber area may persist, despite absence from work, due to altered central motor control mechanisms. Edwards (37) has advocated that work-related muscle pain might be a consequence of an imbalance between motor control and postural muscle activity. Thus the muscular changes in the patients in this study might be secondary to altered central motor control mechanisms.

The difference in fiber size between the patients and the referents in the present study is in contrast to the findings of Larsson et al (15). There are, however, difficulties associated with studying the trapezius muscle which may to some extent explain the discrepancies between the two observations, and perhaps also between the two groups in the present study. As we have previously shown, the muscle fiber composition of the trapezius muscle is inconsistent throughout different portions of the muscle, the inconsistency being most apparent in the descending portion of the muscle $(38,39)$. In the lower regions of the descending portion type I fibers predominate, and the fibers have a larger cross-sectional area. In the upper regions the fibers are smaller and the type II fibers increase in number, especially the type IIB fibers. Consequently biopsies obtained at slightly different levels in this region may show differences with respect to the frequency and size of the fiber types. However, the 
marked difference in the fiber cross-sectional area between the patients and the referents cannot be explained by differences in biopsy sites within this region since these large differences were not found in our previous study on the female trapezius muscle. Interindividual differences and the differences related to gender might also be large, and other factors, such as present and previous physical activity, posture and biomechanical relationships, might also influence muscle morphology. In order to overcome some of the factors, we only included women, all subjects had comparable leisure-time physical activities, and the subjects of the reference group were from the same group as that of Larsson et al (15).

The capillary fiber contact (CF) ratio of the reference group, and also that of the patient group, was higher for the type I fibers than for the type II fibers. These results are similar to findings for human female quadriceps muscle (40). However, our results indicate that the trapezius muscle fibers are less supplied by capillaries than limb muscle fibers. The CF ratio for the trapezius muscle was lower than that reported for the normal female quadriceps (40), the male quadriceps (40-43), and the triceps brachii (43) muscles. The significantly higher CF ratio for the type IIAB fibers in the patients than the corresponding ratio of the referents might be of some interest since an increase in capillarization seems to precede changes in myofibrillar proteins in fiber type transformation (44). Further information regarding this matter may be obtained from the immunohistochemical analyses of trapezius muscle fiber types in progress in our laboratory.

Another significant observation of this study was that, in the patient group, when the CF value was expressed relative to the mean fiber type area, this ratio (CA) was clearly lower for the type $I$, the $I_{I R}$, and the type IIA fibers. This finding might be a result of an increase in muscle fiber area not matched by an increased capillary supply, the result being a larger diffusion distance. Another possibility is a genetic predisposition of the muscle morphology resulting in a low CA ratio. A low CA ratio, regardless of cause, could mean that a smaller blood volume is available for these fibers, and this lower volume could be critical for the uptake of substrates and the removal of metabolites.

Generally, the biochemical analysis of samples from resting muscle of the patients showed a normal content of lactate but significantly lower levels of ATP and phosphocreatine in both fiber types in comparison with that of the healthy referents. There is no easy explanation for this finding. A low resting level of ATP in muscle tissue has been described in patients with rheumatoid arthritis (45), and a minor decrease was observed in patients with chronic trapezius myalgia (15). Interestingly, biopsies obtained from male subjects with the same symptoms all showed normal ATP levels (our unpublished results). This phenomenon might indicate differences between men and women with respect to muscle function and work tolerance, as has previously been suggested (39).

Moth-eaten fibers are of special interest since they have not only been found in trapezius muscle biopsies from patients with chronic muscle pain, but also in the trapezius muscle from perfectly healthy individuals $(15,46)$. They are found only in the type I fiber population and only in the descending portion of the muscle $(38,39)$. It is suggested that the specific anatomic location of these fibers may indicate that this region of the muscle is subjected to strain even during ordinary conditions with no excessive loading $(38,46)$. The different staining patterns of the moth-eaten fibers in the trapezius muscle presented in this study may reflect different mitochondrial reactions. Noteworthy, moth-eaten fibers have also been found in ischemic rat muscle (47).

Ragged-red fibers, which are typical for mitochondrial myopathies (19), have also been found in ischemic rat muscle $(47)$. Larsson and his co-workers $(15,16)$ found ragged-red fibers to be frequent in the trapezius muscle of a group of patients with work-related trapezius myalgia. However, we found ragged-red fibers only in two subjects, one patient and one referent. Serial sections have, however, revealed that the ragged-red fibers may only be present segmentally (48); if so, the segmentation might account for the discrepancies in the number of ragged-red fibers between our studies. The accumulation of lipid droplets in the ragged-red fibers (figure 4) suggests that the fiber metabolism is disturbed. Nevertheless, ragged-red fibers cannot give rise to the low values of energy phosphates found in the trapezius muscle biopsies from our patients. Interestingly, as in mitochondrial myopathies (49), the ragged-red fibers found in the present study were extremely well supplied with capillaries, a finding indicating that the fibers themselves could not be ischemic.

In conclusion, although the results of the present study are based on a small number of subjects and selected cases, they indicate that changes in muscle morphology in chronic trapezius myalgia does exist. However, further studies are needed to confirm whether such changes are related to the development of chronic muscular fatigue and pain caused by static and repetitive worktasks.

\section{Acknowledgments}

The present work was supported by the Swedish Medical Research Council (12X-3934 and 24X-6874 and 02647), the Swedish Work Environment Fund (84-957 and 81-0173), the Swedish Dental Society, and the Medical Faculty of Umeå University.

\section{References}

1. Bateman JE, ed. The shoulder and neck. Philadelphia, PA: WB Saunders, 1978:219-22. 
2. Kilbom A, Persson J, Jonsson B. Disorders of the cervicobrachial region among female workers in the electronic industry. Int $J$ Ind Ergon 1986;1:37-47.

3. Westgaard RH. Measurement and evaluation of postural load in occupational work situations. Eur J Appl Physiol 1988;57:291-304.

4. Jonsson B. The static local component in muscle work. Eur J Appl Physiol 1988;57:305-10.

5. Onishi N, Nomura H, Sahai K, Yamamoto T, Hirayama K, Itami T. Shoulder muscle tenderness and physi$\mathrm{cal}$ features of female industrial workers. J Human Ergol 1976;5:87-102.

6. Kukkonen R, Luopajärvi T, Rigimäki V. Prevention of fatigue amongst data entry operators. In: Kvålseth $\mathrm{TO}$, ed. Ergonomics of workstation design. London: Butterworths, 1983:28-34.

7. Westgaard RH, Aarås A. Postural muscle strain as a causal factor in the development of musculo-skeletal illness. Appl Ergon 1984;15:162-74.

8. Hagberg M, Kvarnström S. Muscular endurance and EMG fatigue in myofascial shoulder pain. Arch Phys Med Rehabil 1984;65:522-5.

9. Hagberg M, Wegman DH. Prevalence rates and odds ratios of shoulder neck disease in different occupational groups. Br J Ind Med 1987;44:602-10.

10. Silverstein BA. The prevalence of upper extremity cumulative trauma disorders in industry [Doctoral dissertation]. Ann Arbor, MI: University of Michigan, 1985.

11. Bjelle A, Hagberg M, Michaelson G. Occupational and individual factors in acute shoulder-neck disorders among industrial workers. Br J Ind Med 1981;38:35663.

12. Hagberg M, Ängquist K-A, Eriksson N-E, Gerdle B, Lindman R, Thornell L-E. EMG-force relationship in patients with occupational shoulder-neck myofascial pain. In: de Groot G, Hollander AP, Huijing PA, van Ingen Schenau GJ, ed. International series on biomechanics: biomechanics XI-A. Amsterdam: Free University Press, 1988:450-4.

13. Herberts P, Kadefors R, Andersson G, Petersén R. Shoulder pain in industry: an epidemiological study on welders. Acta Orthop Scand 1981;52:299-306.

14. Jonsson B, Hagberg M, Sima S. Vocational electromyography in shoulder muscles in an electronic plant. In: Morechi A, Fidelus K, Kalzior K, Wit A, ed. Biomechanic VII-B. Baltimore, MD: University Park Press, 1981:10-5.

15. Larsson SE, Bengtsson A, Bodegård L, Henriksson KG, Larsson J. Muscle changes in work-related chronic myalgia. Acta Orthop Scand 1988;59:552-6.

16. Larsson S-E, Bodegård L. Henriksson KG, Öberg PÅ. Chronic trapezius myalgia: morphology and blood flow studied in 17 patients. Acta Orthop Scand 1990;61: 394-9.

17. Henriksson KG. Muscle pain in neuromuscular disorders and primary fibromyalgia. Eur J Appl Physiol 1988;57:348-52.

18. Brooke MH, Kaiser K. Muscle fiber types: how many and what kind. Arch Neurol 1970;23:369-79.

19. Dubowitz V. Muscle biopsy - a practical approach. 2nd ed. London: Bailliere Tindall, 1985.

20. Buchtal F, Schmalbruch H. Motor unit of mammalian muscle. Physiol Rev 1981;1:90-142.

21. Burke RE. Motor units: anatomy, physiology and functional organization. In: Brooks VB, ed. Handbook of physiology: section 1 . the nervous system; vol II (Motor control). Washington, DC: American Physiological Society 1981:345-422.

22. Essén B, Jansson E, Henriksson J, Taylor W, Saltin B. Metabolic characteristics of fiber types in human skeletal muscle. Acta Physiol Scand 1975;95:153-65.

23. Thorstensson A, Tesch P, Sjödin B, Karlsson J. Actomyosin ATPase, myokinase, CPK and LDH in hu- man fast and slow twitch muscle fibers. Acta Physiol Scand 1977;99:225-9.

24. Saltin B, Gollnick PD. Skeletal muscle adaptability: significance for metabolism and performance. In: Peachey LD, Adrian RG, Geiger SK, ed. Handbook of physiology: sec 10. Bethesda, MD: American Physiological Society 1983:555-631.

25. Padykula HA, Herman E. The specificity of the histochemical method for adenosine triphosphatase. J Histochem Cytochem 1955;3:170-83.

26. Engel WK, Cunningham GG. Rapid examination of muscle tissue: an improved trichrome method for freshfrozen biopsy sections. Neurology 1963;13:919-23.

27. Sternberger LA. Immunocytochemistry. New York, NY: Wiley Medical, 1979.

28. Staron RS, Hikida RS, Hagerman FC. Myofibrillar ATPase activity in human muscle fast twitch subtypes. Histochemistry 1983;78:405-8.

29. Ringqvist I. Fiber types in human masticatory muscles: relation to function. Scand J Dent Res 1974;82:333-55.

30. Harris RC, Hultman E, Nordesjö LO. Glycogen, glycolytic intermediates and high-energy phosphates determinal in biopsy samples of $m$ quadriceps femoris of men at rest: methods and variance of values. Scand J Clin Lab Invest 1974;33:109-20.

31. Lowry OH, Passonneau JV. A flexible system of enzymatic analysis. New York, NY: Academic Press, 1972.

32. Lundin A, Rickardsson A, Thore A. Continuous monitoring of ATP converting reactions by purified firefly luciferase. Anal Biochem 1976;75:611-20.

33. Söderlund K, Hultman E. ATP content in single fibres from human skeletal muscle after electrical stimulation and during recovery. Acta Physiol Scand 1990;139:45966.

34. Baily NTJ. Statistical methods in biology. London: The English University Press Ltd, 1969:33-8.

35. MacDougal JD, Elder GCB, Sale DG, Moroz JR, Sutton JR. Effects of strength training and immobilization on human muscle fibers. Eur J Appl Physiol 1980;43: 25-34.

36. Salmons S, Henriksson J. The adaptive response of skeletal muscle to increased use. Muscle Nerve 1981;4: 94-105.

37. Edwards RHT. Hypotheses of peripheral and central mechanisms underlying occupational muscle pain and injury. Eur J Appl Physiol 1988;57:275-81.

38. Lindman R, Eriksson A, Thornell L-E. Fiber type composition of the human male trapezius muscle: enzyme histochemical characteristics. Am J Anat 1990;189: $236-44$.

39. Lindman R, Eriksson A, Thornell L-E. Fiber type composition of the human female trapezius muscle: enzyme histochemical characteristics. Am J Anat 1991;190: 385-92.

40. Ingjer F. Effects of endurance training on muscle fiber ATP-ase activity, capillary supply and mitochondrial content in man. J Physiol 1979;294:419-32.

41. Andersen P. Capillary density in skeletal muscle of man. Acta Physiol Scand 1975;95:203-5.

42. Andersen P, Henriksson I. Capillary supply of the quadriceps femoris muscle of men: adaptive response to exercise. J Physiol 1977;270:677-90.

43. Schantz P, Henriksson J, Jansson E. Adaptation of human skeletal muscle to endurance training of long duration. Clin Physiol 1983;3:141-51.

44. Pette D, Vrbova G. Invited review: neural control of phenotypic expression in mammalian muscle fibers. Muscle Nerve 1985;8:676-89.

45. Nordemar R, Löfgren O, Fürst P, Harris RC, Hultman E. Muscle ATP content in rheumatoid arthritis - a biopsy study. Scand J Clin Lab Invest 1974;34:185-91.

46. Bengtsson A, Henriksson KG, Larsson J. Muscle biopsy in primary fibromyalgia: light microscopical and 
histochemical findings. Scand J Rheumatol 1986;15: 1-6.

47. Heffner RR, Barron SA. The early effect of ischemia upon skeletal muscle mitochondria. J Neurol Sci 1978; 38:295-315.

48. Henriksson KG, Bengtsson A. Muscle pain with special reference to primary fibromyalgia (PF). In: Dubner $R$, Gebbert GF, Bond MR, ed. Proceedings of Vth world congress on pain. Amsterdam: Elsevier Science Publishers BV, 1988:232-7.

49. Sengers R, Stadhonder A, Bastiansen L. Ragged-red fiber pathology due to micro angiopathy? Muscle Nerve 1986;9(suppl 5):184.

Received for publication: 26 November 1990 